\title{
PENGARUH INOKULASI FUNGI MIKORIZA ARBUSKULA (FMA) PLUS ORGANIK TERHADAP PERTUMBUHAN DAN PRODUKSI JAGUNG PADA ULTISOL
}

\author{
Eddiwal ${ }^{1}$, Amrizal Saidi ${ }^{2}$, Eti Farda Husin ${ }^{2}$, Azwar Rasyidin ${ }^{2}$ \\ IProgram Studi Ilmu-Ilmu Pertanian Program Pasca sarjana Universitas Andalas, \\ ${ }^{2}$ Jurusan Tanah Fakultas Pertanian Universitas Andalas \\ E-mail: edwals.edu2@gmail.com
}

\begin{abstract}
Mycorrhizal symbiosis increases nutrient uptake for plants, resistance to disease, stabilizes soil aggregates and promotes the growth of soil organisms. Fungal hyphae containing glomalin is essential for soil biological processes because of their interactions with plants, soils, and microbes. Activity of AMF in the area of rhizosphere and mycorizosphere will improve the physical, chemical and biological conditions of the soil, thereby providing a healthy soil environment for plants. How the influence of AMF inoculants plus organic ingredients on growth and production of maize on Ultisol needs to be tested in the field. The purpose of this experiment is the application of AMF plus organic inoculants to corn planting, to determine the effect on growth and increase of corn production. Experiments using a randomized block design with four groups. The AMF inoculation treatment was the administration of organic plus inoculant from G. luteum (F1), G. verruculosum (F2), G. versiforme (F3), Multi species of AMF (F4) and without AMF inoculation (F0). The results showed that AMF inoculation had significant effect on total glomalin. G. versiforme has the highest total glomalin, which is $10.59 \mathrm{mg} . \mathrm{g}-1$. The effect of AMF species had no significant effect on aggregate stability, but was significantly different from the treatment without AMF inoculation. The effect of AMF on N, P and $\mathrm{K}$ uptake is significantly different. The highest dry corn kiln production from G. versiforme, which is $8.07 \mathrm{~kg} /$ plot or 4.04 ton / ha, has the same effect as G. luteum (7.98 $\mathrm{kg} /$ plot or 3.99 ton / ha) and Multi AMF ( $7.67 \mathrm{~kg} /$ plot or 3.84 tons / ha). Increased production of dried corn plants inoculated with AMF plus organics can reach $40-83 \%$ higher than the plants without giving the AMF.
\end{abstract}

Key words : mycorizosphere, productivity, rhizosphere, Ultisol

(c) 2018 Eddiwal Eddiwal, Amrizal Saidi, Eti Farda Husin, Azwar Rasyidin

\section{PENDAHULUAN}

Lingkungan tanah merupakan komponen penting untuk kesehatan tanaman, karena tanah mengendalikan pertumbuhan akar, resapan air, aerasi, penyaringan atau penyangga bahan meracun, dan siklus hara. Untuk melakukan fungsi-fungsi ini, komponen biologi tanah beserta sifat fisika dan kimia tanah perlu berinteraksi dalam kondisi yang ideal.

Ultisol yang terdapat di Indonesia memiliki sifat fisika, kimia dan biologi yang jelek. Kestabilan agregat tanah (soil aggregate stability) dari Ultisol tergolong rendah dan kandungan bahan organik sangat rendah $(<2 \%)$.
Hal ini disebabkan karena laju pelapukan bahan organik yang tinggi, serta terakumulasinya liat di lapisan bawah, yang dikenal sebagai horizon argilik atau horizon kandik. Ultisol juga memiliki kejenuhan basa yang rendah, yaitu $<$ $35 \%$ dengan $\mathrm{pH}$ tanah masam (Soil Survey Staff, 1999; Tan, 2000; Subowo, 2010). Kestabilan agregat Ultisol yang rendah menyebabkan agregat mudah pecah menjadi partikel halus yang menutupi pori, serta tanah mudah tererosi. Rendahnya kandungan bahan organik serta tingginya kandungan liat pada Ultisol juga menyebabkan air yang terikat pada pori mikro sulit diambil akar tanaman. Kondisi demikian menyebabkan pertumbuhan 
tanaman kurang baik, terutama tanaman semusim seperti jagung yang akan mengalami banyak kendala pada Ultisol.

Penanaman jagung pada Ultisol menghasilkan produktivitas sangat rendah. Edi dan Silvia (2011) melaporkan bahwa sebbahagian besar penanaman jagung di Propinsi Jambi dilakukan pada Ultisol, dimana rata-rata produktivitas jagung pada periode 2005-2009 (data BPS,2009) adalah 3,54 t/ha. Mereka menjelaskan bahwa produksi jagung dalam periode ini hanya 30 sampai $50 \%$ dari potensi hasil tanaman jagung. Hasil yang sama juga dilaporkan oleh Andriko dan Sirappa (2005) bahwa produktivitas jagung yang di tanam pada lahan kering di Maluku dalam periode 1996-2001 rata-rata adalah sebesar 1,4 t/ha. Fakta ini menunjukkan bahwa produktivitas jagung $<5$ ton.ha ${ }^{-1}$ pada Ultisol tergolong rendah (Purwanto, 2011).

Salah satu cara meningkatkan produktivitas tanaman jagung pada Ultisol yang juga dapat memperbaiki sifat fisika tanah secara berkelanjutan adalah pemanfaatan Fungi Mikoriza Arbuskula (FMA). Sifat fisika Ultisol sulit diatasi dengan upaya pengelolaan lahan, baik melalui pengolahan tanah ataupun pemupukan (Subowo, 2010).

Fungi Mikoriza Arbuskula berasosiasi mutualisme dengan sebagian besar tanaman, dimana FMA memperoleh karbon dari tanaman dan tanaman menerima suplai unsur hara terutama Posfor $(\mathrm{P})$, nitrogen $(\mathrm{N})$ dan air dari FMA. Hifa jamur dan biomolekul, seperti glomalin sebagai komponen hifa penting untuk proses biologi tanah karena interaksi mereka dengan tanaman, tanah, dan mikroba tanah (Nichols, 2008). Hifa FMA juga mampu menjelajahi tanah pada pori mikro, dimana akar tanaman tidak dapat melewatinya (Jones, 2014) dan memiliki luas permukaan yang lebih besar dari akar tanaman (Tan, 2000).

Fungi mikoriza sangat membutuhkan bahan organik sebagai sumber N. Penemuan akhir-akhir ini membuktikan bahwa, FMA juga berperan merombak bahan organik (kemampuan saprotrofik) dan memperoleh $\mathrm{N}$ dari hasil perombakan tersebut untuk kebutuhan metabolisme dan perkembangannya.
Pertumbuhan hifa jamur meningkat karena adanya bahan organik dan tidak tergantung pada tanaman inang (Hodge, Campbell dan Fitter, 2001; Leigh et al., 2009; Hodge dan Fitter 2010). Hasil penelitian sebelumnya menunjukkan bahwa, FMA nyata meningkatkan hasil glomalin lebih tinggi jika ditambahkan bahan organik setara $30 \mathrm{mg} \mathrm{N}$ dari bahan hijauan tithonia (Eddiwal et al. 2014). Pengaruh glomalin ini nyata memperbaiki fisika tanah, sehingga memberikan kondisi optimum bagi pertumbuhan tanaman jagung (Amrizal et al. 2015).

Pemanfaatan FMA untuk penanaman jagung pada tanah Ultisol di lapangan perlu dilakukan untuk mengevaluasi penggunaan inokulan FMA plus bahan organik. Bagaimana pengaruh inokulan FMA plus bahan organik terhadap pertumbuhan dan peningkatan produksi jagung perlu diteliti. Tujuan dari penelitian ini adalah mengetahui pengaruh inokulan FMA plus organik terhadap tanaman jagung dan peningkatan produksi pipilan kering pada Ultisol.

\section{BAHAN DAN METODA}

Penelitian menggunakan bahan inokulan FMA dalam media pasir yang ditambahkan bubuk bahan organik dari hijauan tithonia setara $30 \mathrm{mg} \mathrm{N}$. Bahan inokulan FMA yang digunakan adalah G. luteum (13 spora/g), G. verruculosum (4 spora/g) dan $G$. versiforme $(8,5 \mathrm{spora} / \mathrm{g})$ serta Multi Spesies FMA (5 spora/g). Jumlah spora dari bahan inokulan FMA yang digunakan adalah sebanyak $\geq 30$ spora per tanaman (INVAM; //www:invam.caf.wvu.edu/ methods/cultures). Tanaman menggunakan jagung variertas NK-99.

Penelitian ini dilaksanakan pada Ultisol lokasi percobaan BPTP UPT Gunung Medan Kabupaten Darmasraya Sumatera Barat. Pelaksanaan penelitian selama 4 bulan, mulai bulan Agustus s/d Nopember 2014.

Penempatan percobaan di lapangan menggunakan Rancangan Acak Kelompok (RAK) dengan ulangan 4 kelompok. Perlakuan adalah inokulasi dari 5 perlakuan spesies FMA pada takaran dosis inokulan $20 \mathrm{~g}$ 
per tanaman ( $\geq 30$ spora) dalam media pasir plus bahan organik setara $30 \mathrm{mg} \mathrm{N}$ dari bahan hijauan tithonia. Bahan hijauan tithonia yang digunakan adalah bubuk kering dengan kandungan $\quad \mathrm{N}$ sebesar $3.08 \%$, sehingga takaran pemberian bahan hijauan sebanyak 975 mg. Inokulan FMA yang digunakan berasal dari spesies FMA yang sudah terpilih dari pengujian sebelumnya serta inokulan multi spesies FMA dari gabungan inokulan 9 spesies FMA indigenous pada Ultisol. Multi spesies FMA terdiri dari Acaulospora scrobiculata, Glomus etunicatum, Glomus luteum, Glomus mosseae, Glomus verruculosum, Glomus versiforme, Scutellospora gregaria, Scutellospora heterogama and Gigaspora sp. Perlakuan inokulasi FMA plus organik adalah $G$. luteum (F1), G. verruculosum (F2), $G$. versiforme (F3), serta Multi spesies FMA (F4) dan tanpa pemberian FMA (F0).

Penanaman pada bedengan dengan plot percobaan menurut Sistem Legowo Tanaman Jagung (Balitsereal, 2013) dengan jarak tanam jagung $(100 \quad-50) \quad \mathrm{cm} \quad \mathrm{x} \quad 20 \mathrm{~cm} \quad(1$ tanaman/lubang) atau populasi 66.000 batang per ha. Bedengan dibuat dengan lebar $120 \mathrm{~cm}$ dan jarak antar bedengan $30 \mathrm{~cm}$ sehingga terdapat 3 bedengan setiap plot percobaan. Jarak tanam antar barisan pada bedengan adalah $50 \mathrm{~cm}$ dan antara bedengan satu dengan lainnya $100 \mathrm{~cm}$.

Benih jagung ditanam dengan jarak 50 $\mathrm{cm}$ antar baris tanaman dalam 1 bedengan (terdapat 6 baris tanaman per plot) dan jarak tanam dalam barisan $20 \mathrm{~cm}$ (terdapat 22 tanaman per baris), sehingga jumlah populasi diperoleh 132 tanaman per plot. Penanaman dilakukan pada sore hari dengan cara tugal/digali lubang pada titik tanam dan diisi inokulan FMA 2/3 dosis perlakuan dari masing-masing spesies FMA. Benih jagung sebanyak 2 benih segera ditanam setelah pemberian inokulan FMA dan ditutup dengan $1 / 3$ sisa inokulan FMA. Pada umur 2 minggu dipelihara 1 tanaman yang tumbuh baik.

Tanaman jagung dipelihara selama penelitian dengan cara memberishkan gulma, pemberian pupuk dan penyiraman. Pemberian pupuk anorganik dilakukan dua minggu sesudah tanam secara tugal pada jarak $15 \mathrm{~cm}$ dari pangkal batang. Pupuk yang diberikan $50 \%$ dari dosis standar, yaitu Urea sebanyak $150 \mathrm{~kg} \mathrm{ha}^{-1}$ (setara 2,27 g.batang ${ }^{-1}$ atau 340 g.plot ${ }^{-1}$ ) diberikan dua kali (separoh dosis pada pemberian kedua pada umur 6 minggu sesudah tanam), SP-36 sebanyak $50 \mathrm{~kg}$ ha $^{-1}$ (setara 0,75 g.batang ${ }^{-1}$ atau 112,5 g.plot $^{-1}$ ) dan $\mathrm{KCl}$ sebanyak $75 \mathrm{~kg} \mathrm{ha}^{-1}$ (setara 1,2 g.batang ${ }^{-1}$ atau 180 g.plot ${ }^{-1}$ ).

Pengamatan tanah dilakukan pada awal dan akhir penelitian yaitu pengamatan sifat fisika tanah dan kimia tanah. Sifat tanah yang diamati adalah stabilitas agregat tanah (Six et al. 2000), kadar air tanah pada $\mathrm{pF} 1,0 ; \mathrm{pF} 2,0$; $\mathrm{pF}$ 2,54 dan $\mathrm{pF}$ 4,2 dengan Pressure plate apparatus dan Pressure membrane apparatus. Total ruang pori tanah (TRP), Berat volume tanah (BV), \% ruang pori, pori drainase dan pori air tersedia. Sifat kimia yaitu $\mathrm{pH}$ tanah, C organik, N-total, $\mathrm{P}$ tersedia, Al dd tanah, KTK tanah dan Kejenuhan Basa. Total glomalin ditentukan dengan cara mengekstrak (extraction) contoh tanah pada tanah awal dan akhir penelitian menurut metoda publikasi oleh USDA:

(www.ars.usda.gov/.../ad hoc/54450000Gloma lin/Glomalin\%20Extraction.pdf.)

dan mengukur kadar protein atau glomalin publiksi oleh USDA:

(www.ars.usda.gov/.../Bradford\%20Total\%20P rotein\%20Assay.pdf).

Pengamatan pada tanaman meliputi pengamatan infeksi mikoriza (Giovannetti dan Mosse, 1980), pertumbuhan tanaman jagung serta serapan hara $\mathrm{N}, \mathrm{P}, \mathrm{K}$ tanaman dan produksi. Produksi diamati pada saat panen umur 110 hari yaitu berat segar tongkol, jumlah baris per tongkol, berat 100 butir pipilan kering dan berat pipilan kering per batang pada kadar air $14 \%$.

Data diolah dengan kriteria perbandingan analysis of variance (ANOVA) dan uji lanjut LSD (Fisher's least significant difference tests) pada taraf $5 \%$. Pengolahan data menggunakan Program CooStat versi 8.0.

https://doi.org/10.25077/jsolum.15.2.50-59.2018 


\section{HASIL DAN PEMBAHASAN}

\section{Karakteristik Tanah Lokasi Penelitian}

Lokasi Ultisol untuk percobaan lapangan adalah kebun percobaan Balai Pengkajian Teknologi Pertanian Sumatera Barat UPT BPTP Gunung Medan. Tanah lokasi percobaan termasuk famili Tropohumult Orthoxik, berasal dari bahan induk Tuf vulkan (Team 4 Architects \& Consulting Engineers, 1982). Ultisol pada lokasi ini dipilih untuk percobaan demplot adalah karena memiliki musim kemarau lebih ekstrim dari daerah lain. Kondisi ini dapat membantu untuk memahami peranan FMA dan bahan organik terhadap pertumbuhan dan produksi jagung di lapangan.

Sifat tanah lokasi percobaan bereaksi masam dengan $\mathrm{C}$ organik dan hara antara sedang sampai rendah, terutama ketersediaan $\mathrm{P}$ sangat rendah. Kandungan glomalin sebanyak $1,34 \mathrm{mg} \cdot \mathrm{g}^{-1}$ tanah berada pada kisaran terendah sebagaimana dilaporkan Wright dan Upadhyaya (1998). Sifat fisika tanah kurang baik, dimana pori drainase cepat tergolong tinggi, serta pori drainase lambat dan pori air tersedia termasuk rendah. Hasil analisis tanah awal selengkapnya seperti pada Tabel 1.

Tabel 1. Hasil analisis tanah awal dari lokasi percobaan lapang

\begin{tabular}{|c|c|c|c|c|c|}
\hline No. & Analisis & $\begin{array}{c}\text { Hasil } \\
\text { analisis }\end{array}$ & No. & Analisis & $\begin{array}{c}\text { Hasil } \\
\text { analisis }\end{array}$ \\
\hline & Ciri Kimia Tanah & & & Ciri Fisika Tanah & \\
\hline 1 & $\mathrm{pH} \mathrm{H} 2 \mathrm{O}$ & 4.93 & 1 & $\mathrm{BV}\left(\mathrm{g} \cdot \mathrm{cm}^{-3}\right)$ & 0.84 \\
\hline 2 & $\mathrm{pH} \mathrm{KCl}$ & 4.12 & 2 & Total Ruang Pori (\%) & $60.6^{\mathrm{s}}$ \\
\hline 3 & C organik (\%) & $1.26^{\mathrm{r}}$ & 3 & $\mathrm{pF} 1.0$ & 53.4 \\
\hline 4 & $\mathrm{~N}$ total $(\%)$ & $0.28^{\mathrm{s}}$ & 4 & $\mathrm{pF} 2.0$ & 42.3 \\
\hline 5 & P tersedia (ppm) & $7.35^{\mathrm{sr}}$ & 5 & $\mathrm{pF} 2.54$ & 36.2 \\
\hline 6 & K-dd (cmol.kg-1) & $0.42^{\mathrm{s}}$ & 6 & $\mathrm{pF} 4.2$ & 28.5 \\
\hline 7 & Ca-dd $\left(\mathrm{cmol}^{.} \mathrm{kg}^{-1}\right)$ & $5.61^{\mathrm{s}}$ & 7 & Pori makro & 24.4 \\
\hline 8 & $\mathrm{Mg}-\mathrm{dd}\left(\mathrm{cmol} . \mathrm{kg}^{-1}\right)$ & 0.47 & 8 & Pori mikro & 36.2 \\
\hline 9 & $\mathrm{Na}-\mathrm{dd}\left(\mathrm{cmol} \cdot \mathrm{kg}^{-1}\right)$ & 0.28 & 9 & Pori drainase cepat & $18.3^{t}$ \\
\hline 10 & Al-dd $\left(\mathrm{cmol} \mathrm{kg}^{-1}\right)$ & 1.63 & 10 & Pori drainase lambat & $6.1^{\mathrm{r}}$ \\
\hline 11 & KTK $\left(\mathrm{cmol} \cdot \mathrm{kg}^{-1}\right)$ & 18.68 & 11 & Pori air tersedia $(\%)$ & $7,7^{\mathrm{r}}$ \\
\hline 12 & Kejenuhan Basa (\%) & 36.29 & 12 & Stabilitas aggregat (NSI) & 0.81 \\
\hline 13 & Kejenuhan Al (\%) & 19.38 & & & \\
\hline 14 & Total Glomalin $\left(\mathrm{mg} \mathrm{g}^{-1}\right)$ & 1.34 & & & \\
\hline
\end{tabular}

Keterangan: $\mathrm{r}=$-rendah, $\mathrm{s}=$ sedang, $\mathrm{sr}=$ sangat rendah, $\mathrm{t}=$ tinggi

\section{Pengaruh Inokulan FMA Plus terhadap Fisika Tanah}

Pemberian inokulan FMA memberikan pengaruh yang berbeda terhadap fisika tanah, namun secara statistik tidak terlalu nyata berbeda. Pengaruh inokulasi dengan $G$. luteum dan $G$. versiforme terhadap total ruang pori lebih baik dari yang lainnya. Pengaruh yang sama juga terlihat pada pori mikro dan pori makro. Akan tetapi, pori air tersedia pada $G$. versiforme paling tinggi.

Total ruang pori pada $G$. luteum dan $G$. versiforme terlihat lebih baik dari perlakuan lainnya. Fenomena yang relatif sama juga tergambar pengaruhnya terhadap pori mikro, pori makro dan pori air tersedia. Pengaruh yang berbeda terlihat pada pori drainase cepat. Gambaran pengaruh penanaman jagung terhadap pori drainase cepat terjadi penurunan dibanding perlakuan lainnya. Penurunan yang signifikan terhadap pori drainase cepat terlihat pada $G$. versiforme. Sebaliknya penanaman jagung menghasilkan peningkatan terhadap pori drainase lambat, terutama lerlihat pada $G$. versiforme. Perbedaan fisika tanah yang dipengaruhi inokulasi FMA dapat dilihat pada Gambar 1. 


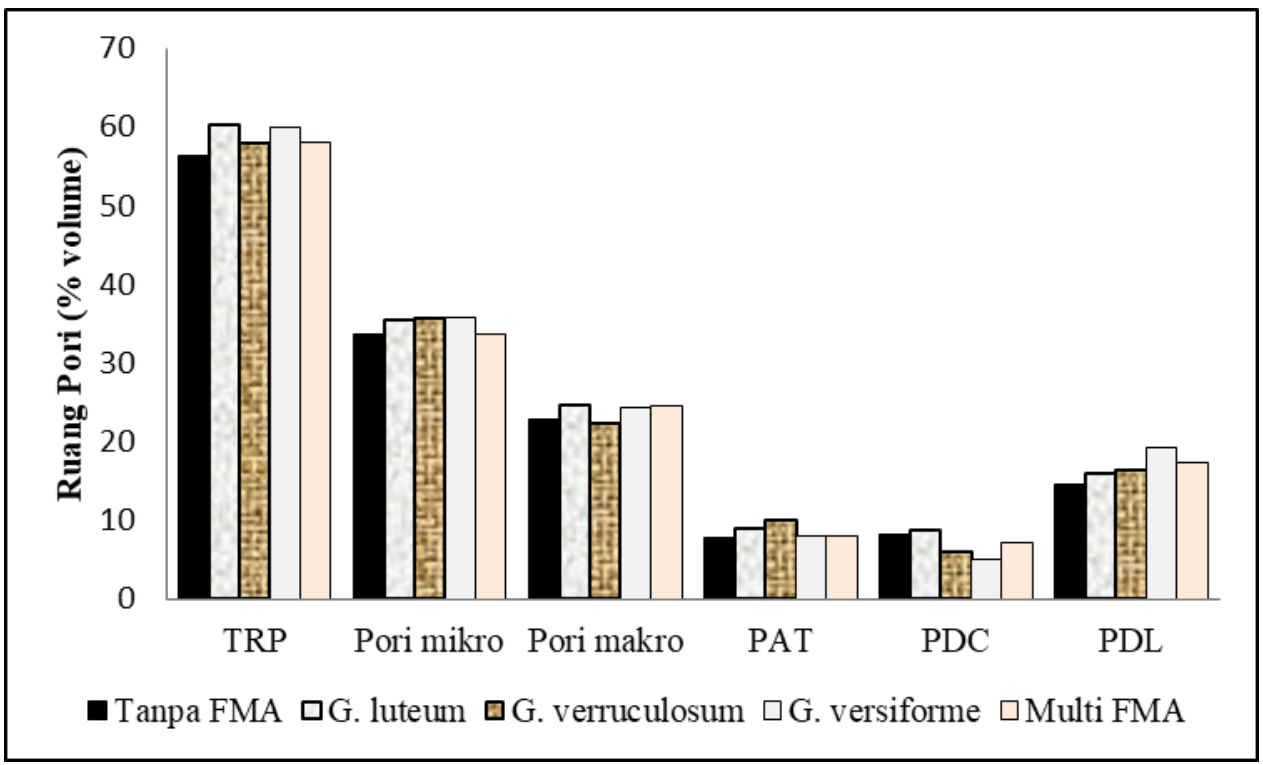

Gambar 1. Perbedaan sifat fisika tanah yang dipengaruhi inokulasi FMA plus bahan organik.

Berdasarkan pengamatan fisika tanah pada percobaan lapangan menunjukkan pengaruh inokulasi FMA plus organik lebih baik, terutama inokulan dari G. luteum dan $G$. versiforme.

\section{Serapan Hara Tanaman}

Pengaruh pemberian inokulan FMA Plus tidak sama terhadap konsentrasi hara dan bobot kering tanaman sehingga berpengaruh terhadap serapan hara tanaman. Serapan hara $\mathrm{N}$, $\mathrm{P}$ dan $\mathrm{K}$ tanaman menunjukkan pengaruh yang sangat nyata akibat pemberian inokulan FMA Plus.

Salah satu indikator kebugaran pertumbuhan tanaman bermikoriza adalah serapan hara tanaman. Pengaruh FMA terhadap serapan $\mathrm{N}, \mathrm{P}$ dan $\mathrm{K}$ tanaman berbeda nyata, dimana kandungan $\mathrm{N}$ tertinggi adalah $273.42 \mathrm{mg}$ pada $G$. versiforme dan berbeda nyata dengan pemberian Multi FMA dan tanpa FMA. Kecenderungan yang sama terlihat dalam kandungan $\mathrm{P}$ dan $\mathrm{K}$ dari tanaman pada $G$. luteum dan $G$. versiforme juga lebih tinggi sehingga serapan $\mathrm{P}$ dan $\mathrm{K}$ nyata lebih tinggi dari lainnya. Perlakuan tanpa FMA memiliki serapan hara yang paling rendah dan berbeda nyata dengan pemberian inokulan FMA Plus.

Perbedaan konsentrasi $\mathrm{N}$ tanaman juga berhubungan dengan bobot kering bagian atas tanaman sehingga berpengaruh terhadap serapan hara tanaman. Bobot kering tanaman tertinggi adalah $28.95 \mathrm{mg}$ pada $G$. versiforme dan tidak berbeda nyata dengan $G$. luteum (26.49 $\mathrm{mg}$ ) dan G. verruculosum (26.34 mg). Tanaman tanpa pemberian FMA memiliki bobot kering terendah yaitu $20.08 \mathrm{mg}$ dan tidak berbeda nyata dengan perlakuan Multi FMA tetapi berbeda nyata dengan yang lainnya. Fakta ini menunjukkan peranan FMA dalam penyerapan hara terutama $\mathrm{N}$ dan $\mathrm{P}$ sehingga mempengaruhi pertumbuhan bobot kering tanaman. Perbedaan pengaruh FMA terhadap serapan hara tanaman dapat dilihat pada Gambar 2.

Berdasarkan indikator serapan hara tanaman menunjukkan bahwa inokulasi FMA plus bahan organik pada $G$. luteum dan $G$. versiforme nyata lebih baik dari perlakuan lainnya.

\section{Produksi Pipilan Kering}

Pemberian inokulan FMA Plus pada tanaman jagung di lapangan mampu meningkatkan kandungan total glomalin dalam tanah dan meningkatkan penyerapan hara tanaman sehingga berpengaruh nyata terhadap produksi jagung. Produksi total glomalin dan produksi pipilan kering adalah berbeda sangat nyata akibat pemberian inokulan FMA Plus 
organik. Inokulasi dengan $G$. versiforme menghasilkan total glomalin tertinggi yaitu $10.59 \mathrm{mg} \cdot \mathrm{g}^{-1}$ dan produksi pipilan kering jagung sebesar 13.04 kg.petak ${ }^{-1}$ (setara 6.52 ton.ha $\left.{ }^{-1}\right)$. Produksi pipilan kering tertinggi adalah pada $G$. versiforme, tidak berbeda nyata dengan G. verruculosum (5.88 ton.ha ${ }^{-1}$ ) dan Multi FMA (5.67 ton.ha $\left.{ }^{-1}\right)$ Sebaliknya produksi terendah pada tanaman tanpa inokulasi FMA sebesar 3.56 ton.ha ${ }^{-1}$ atau 7,12 kg.petak ${ }^{-1}$ berbeda nyata dengan perlakuan lainnya. Perbedaan pengaruh pemberian inokulan FMA Plus terhadap total glomalin dan produksi pipilan kering dapat diamati pada Gambar 3.

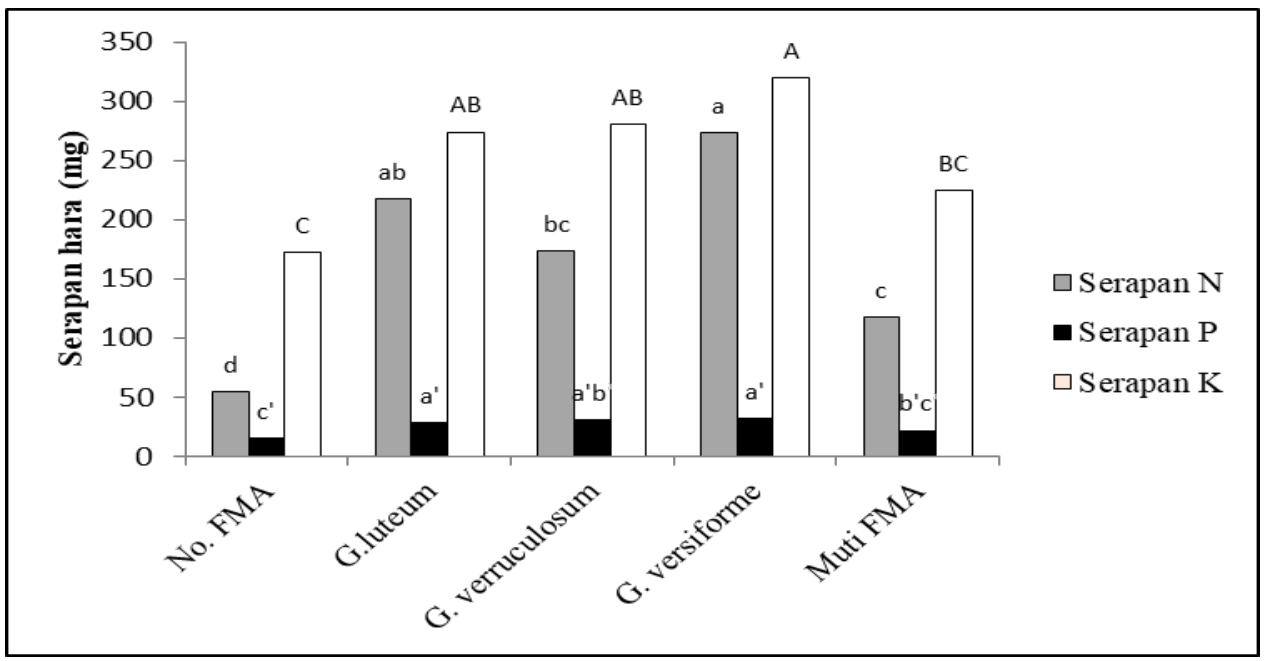

Gambar 2. Pengaruh inokulan FMA Plus terhadap Serapan hara N, P dan K tanaman. Huruf yang sama pada kolom tidak berbeda nyata uji LSD pada taraf 0.05 .

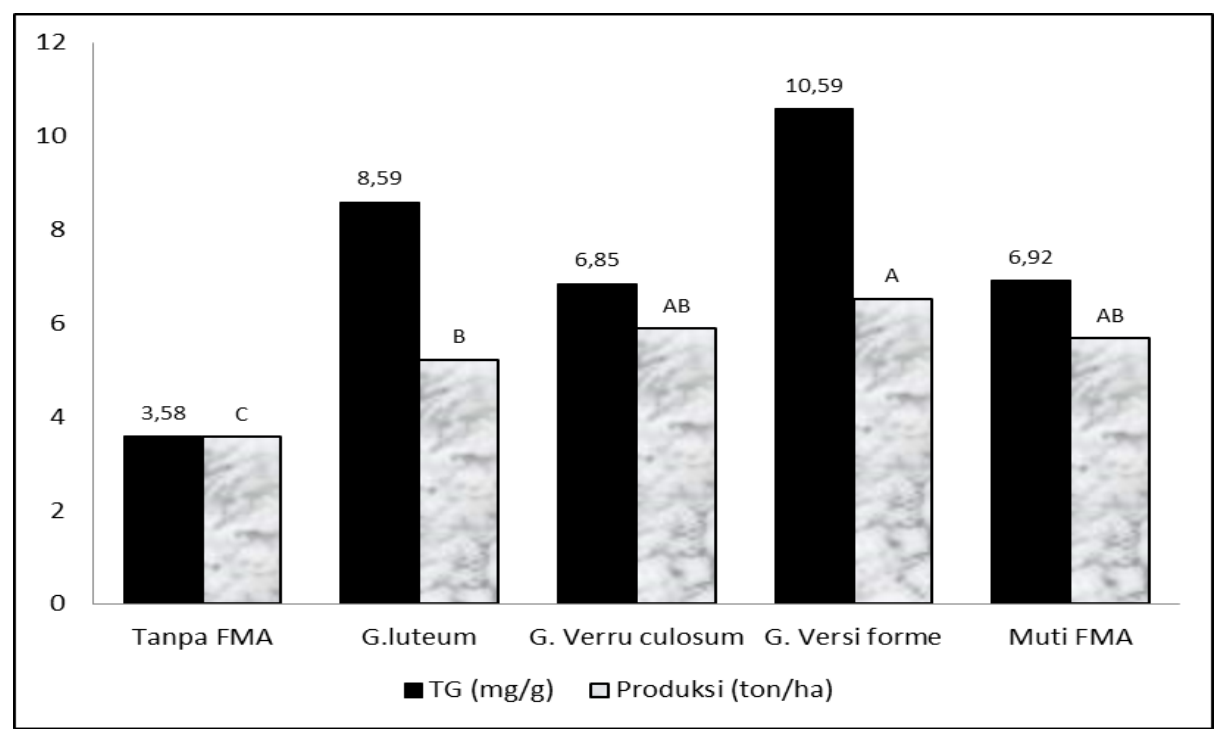

Gambar 3. Pengaruh inokulan FMA Plus terhadap total glomalin dan Produksi pipilan kering Huruf besar yang sama pada kolom produksi tidak berbeda nyata uji LSD, 0.05. 
Peningkatan produksi pipilan kering dari tanaman yang diinokulasi dengan FMA plus bahan organik dapat mencapai $40-83 \%$ dari tanaman tanpa pemberian FMA. Hal ini dapat dijelaskan bahwa tanaman yang bermikoriza memiliki kemampuan untuk meningkatkan penyerapan hara oleh tanaman dari dalam tanah serta memberikan kondisi fisika tanah yang lebih baik. Perkembangan hifa FMA dalam membantu penyerapan hara dapat dilihat dari total glomalin yang lebih tinggi pada tanaman bermikoriza (Driver et al. 2005). Hifa FMA mampu meningkatkan penyerapan $\mathrm{P}$ yang terfiksasi untuk tanaman (Husin, 1992; Husin et al. 2012). FMA juga mampu mengeksploitasi $\mathrm{N}$ dari sumber bahan organik yang tidak dapat diserap akar tanaman. Sebahagian $\mathrm{N}$ digunakan untuk kebutuhan metabolisme FMA dan sebahagian ditransfer pada tanaman. Sebahagian besar N yang diambil dari sumber organik tanah digunakan untuk perkembangan hifa yang progresif (Hodge et al. 2001; Leight et al. 2009; Hodge dan Fitter 2010).

Hasil penelitian pada Gambar 30 terhadap serapan $\mathrm{N}$ yang tinggi pada tanaman bermikoriza dapat meningkatkan bobot kering bagian atas tanaman. Hodge dan Fitter (2010) juga melaporkan bahwa tanaman yang diinokulasi dengan FMA dan diberi $\mathrm{N}$ organik sebanyak $1 \mathrm{~g}$ (mengandung $20.83 \mathrm{mg} \mathrm{N}$ ) berlabel ${ }^{15} \mathrm{~N}$ dan ${ }^{13} \mathrm{C}$, terjadi peningkatan pertumbuhan batang dan kandungan $\mathrm{N}$ batang dan akar. Selanjutnya dari pengujian pada percobaan pot menggunakan media steril oleh Eddiwal et al. (2014) menunjukan terjadinya peningkatan nyata lebih tinggi terhadap konsentrasi $\mathrm{N}$ dan $\mathrm{P}$ pada tanaman bermikoriza dengan pemberian 20 dan $30 \mathrm{mg} \mathrm{N}$ dari bahan hijauan tithonia. Hal ini juga berkorelasi positif dengan total glomalin dari media tanam sebagai representasi dari perkembangan hifa yang lebih progresif. Hifa FMA kaya dengan $\mathrm{N}$, dimana hifa eksternal memiliki konsentrasi $\mathrm{N}$ mencapai $4-7$ kali dari bagian atas tanaman, dan bahkan 10 kali lebih tinggi dari akar tanaman (Hodge dan Fitter, 2010). Konsentrasi $\mathrm{N}$ yang tinggi pada hifa merupakan fakta bahwa glomalin sebagai penyusun dinding hifa dan spora FMA (Driver et al. 2005) merupakan sumber $\mathrm{N}$ bagi tanah (Rillig, 2004; Rillig et al. 2001; Lovelock et al. 2004).

Hifa FMA dalam tanah juga mampu menciptakan kondisi fisika yang baik bagi perakaran tanaman dan organisme tanah, sehingga memberikan kesuburan secara biologi dari aktifitas organisme tersebut. Jaringan hifa FMA dapat membentuk struktur tanah yang baik (Horman et al., 2011). Kandungan glomalin pada hifa dan dinding spora menyatukan kembali partikel tanah yang terdispersi membentuk agregat mikro (ukuran $<0,25 \mathrm{~mm}$ ) yang lebih stabil (Wright dan Upadhyaya, 1996; 1998; Rillig dan Mummey, 2006; Treseder dan Turner 2007; Borie et al. 2008; Wright at al. 2001). Agregat mikro menyatu bersama-sama dengan hifa FMA membentuk aggregat makro (ukuran $>0,25$ $\mathrm{mm}$ ) untuk menghasilkan struktur tanah lebih baik (Wright et al. 2001; Hoorman et al., 2011). Meskipun efek bakteri terhadap pembentukan agregat tanah ditemukan terutama pada aggregat mikro, tetapi efek mikoriza lebih jelas pada pembentukan aggregat makro (Rillig dan Mummey, 2006). Selanjutnya, Mardatin dan Rillig (2011) menambahkan bahwa FMA dapat membentuk dan mempertahankan agregat makro lebih stabil. Glomalin yang terkandung pada hifa bersifat menolak air (water repellency), sehingga mendorong pembentukan agregat makro dan terlindung dari penghancuran oleh butir hujan. Mekanisme penyatuan agregat mikro ini terbentuk dengan cara hifa melewati ruang antara agregat mikro dan merekat satu sama lainnya menjadi agregat yang lebih besar. Gabungan agregat mikro ini akan menghasilkan struktur tanah yang baik berdiameter $<0,5 \mathrm{~cm}$ (DeForest, 2009).

\section{KESIMPULAN}

Hasil percobaan di lapangan menunjukkan bahwa inokulasi FMA plus bahan organik yang terbaik adalah $G$. versiforme memiliki total glomalin tertinggi, yaitu $10.59 \mathrm{mg} \cdot \mathrm{g}^{-1}$. Produksi pipilan kering jagung dari $G$. versiforme dihasilkan paling 
tinggi, yaitu sebesar 3.04 kg.petak ${ }^{-1}$ atau 6.52 ton.ha ${ }^{-1}$ dan secara statistik berpengaruh sama dengan $G$. verruculosum (11.76 kg.petak ${ }^{-1}$ atau 5.88 ton.ha $^{-1}$ ).

Peningkatan produksi pipilan kering dari tanaman jagung yang diinokulasi dengan FMA plus bahan organik dibanding tanpa pemberian FMA dapat mencapai $40-83 \%$.

\section{DAFTAR PUSTAKA}

Andriko Noto Susanto dan M.P. Sirappa 2005. Prospek dan Strategi Pengembangan Jagung untuk mendukung ketahanan pangan di Maluku. Jurnal Litbang Pertanian, 24 (2) hal 70-79.

Balitsereal, 2013. Sistem Legowo Tanaman Jagung. Balai Penelitian Tanaman Serealia, Badan Litbang Pertanian. Maros Sulawesi Selatan. balitsereal.litbang.deptan.go.id. 30 April 2013.

Borie, F., R. Rubio, dan A. Morales. 2008. Arbuscular mycorrhyzal fungi and soil aggregation. R. C. Suelo Nutr. Veg. Vol. 8 (2) : 9 -18, diunduh 27 Desember 2011.

DeForest, J. 2009. Achieving solid soil structure is keystone to healthy soils. The Department of environmental and plant biology at Ohio University, diunduh 20 Agsutus 2014.

Driver, J. D., W. E. Holben, dan M. C. Rillig. 2005. Characterization of glomalin as a hyphal wall component of arbuscular mycorrhizal fungi. Soil Biology and Biochemistry, Vol. 37 : $101-106$, diunduh 27 Desember 2011.

Eddiwal, A. Saidi, E.T. Husin dan A. Rasyidin. 2014. Effect of arbuscular mycorrhizal fungi (AMF) and organic nitrogen of the forages Tithonia on glomalin production. Makalah Seminar Internasional " 1 st International Conference on Development

\section{Management and Public Policy" Pascasarjana Universitas Andalas, Padang 20 November 2014.}

Edi, S dan E. Salvia. 2011. Inovasi teknologi budidaya dalam rangka pengembangan usaha tani jagung di provinsi Jambi. Balai pengkajian Teknologi Pertanian Jambi. Prosiding Pekan Serealia Nasional tahun 2011.

Giovannetti, M dan B. Mosse, 1980. An evaluation of techniques for measuring vesicular arbuscular mycorrhizal infection in roots. New Phytol. Vol. 84 : 489 - 500, diunduh 16 Maret 2012.

Hodge, A., C. D. Campbell dan A. H. Fitter. 2001. An arbuscular mycorrhizal fungus accelerates decomposition and acquires nitrogen directly from organic material. Nature. Vol. 413 : 297-299, 16 Maret 2012.

Hodge, A dan A. H. Fitter. 2010. Substantial nitrogen acquisition by arbuscular mycorrhizal fungi from organic material has implications for $\mathrm{N}$ cycling. PNAS vol 107 (31) : $13754-$ 13759, diunduh 16 Maret 2012.

Hoorman J. J., J. C. de Moraes (Juca) Sa and R. Reader. 2011. The Biology of Soil Compaction. American Society of Agronomy. Crops and Soils Magazine (July-August 2011) : 4 - 10, diunduh 27 Desember 2011.

Husin E. F. 1992. Perbaikan sifat kimia tanah Podzolik dengan pemberian pupuk hijau dan FMA serta efeknya terhadap serapan hara dan hasil tanaman jagung. Disertasi, Program Doktor Universitas Padjadjaran. Bandung.

Husin, E. F., A. Syarif dan Kasli. 2012. Mikoriza sebagai pendukung system pertanian berkelanjutan dan 
berwawasan linkungan. Andalas University Press. Padang. p. 100.

Jones, C. 2014. Mycorrhizal fungi powerhouse of the soil. The Natural Farmer, Summer 2014. B-14, diunduh 12 Oktober 2015.

Leigh, J., A. Hodge dan A.H. Fitter. 2009. Arbuscular mycorrhizal fungi can transfer substantial amounts of nitrogen to their host plant from organic material. New Phytologist.181 : 199-207, diunduh 16 Maret 2012.

Lovelock, C. E., S. F. Wright dan K. A. Nichols. 2004. Using glomalin as an indictor for arbuscular mycorrhizal hyphal growth: an example from a tropical rain forest soil. Soil Biol. Biochem. 36 : 1009 - 1012, diunduh 27 Desember 2011.

Mardatin, N.F. dan M.C. Rillig. 2011. Mycelium of mycorrhizal fungi increases soil aggregates. Dalam Prosiding Seminar Mikoriza. Bandar Lampung, 20-21 juli 2011. Asosiasi Mikoriza Indonesia. Hal. 75-79.

Nichols, K. A. 2008. Indirect contribution of AM Fungi and soil aggregation to plant growth and protection. In Siddiqui $Z$. A., Akhtar M. S., and Futai K. Editor. Mycorrhizae : Sustainable Agriculture and Forestry. Sringer.com. p. 177194, diunduh 27 Desember 2011.

Purwanto, S. 2011. Perkembangan produksi dan kajian dalam peningkatan produksi jagung. Direktorat Budidaya Serealia. Dirjen Tanaman pangan. Prosiding Pekan Serealia Nasional tahun 2011.

Rillig, M.C., S.F. Wright,. K.A. Nichols, W. F. Schmidt, dan M. S. Torn. 2001. Large contribution of arbuscular mycorrhizal fungi to soil carbon pools in tropical rain forest. Plant and Soil, 233 : 167177, diunduh 27 Desember 2011.

Rillig, M. C. 2004. Arbuscular mycorrhizae, glomalin and soil aggregation. Can. J. Soil Sci Vol. 84 : 355 - 363, diunduh 27 Desember 2011.

Rillig, M. C. dan D. L. Mummey. 2006. Mycorrhizas and soil structure. New Phytologist Vol. 171 : 41 - 53, diunduh 27 Desember 2011.

Six, J., E. T. Elliott and K. Paustian. 2000. Soil structure and soil organic matter : II. A normalized stability index and the effect of mineralogy. Soil Science Soc. Am. J. 64 : 1042-1049, diunduh 16 Maret 2012.

Soil Survey Staff, 1999. Soil Taxonomi.A basic system of soil classification for making and interpreting soil survey.Secon edition. United States Department of Agriculture.

Subowo, G. 2010. Strategi efisiensi penggunaan bahan organik untuk kesuburan dan produktivitas tanah melalui pemberdayaan sumberdaya hayati tanah. Jurnal Sumberdaya Lahan Vol. 4 (1) : 13 - 25.

Team 4 Architects \& Consulting Engineers 1982. Laporan Survei tanah dan Kesesuaian lahan Balai Penelitian Tanaman Pangan Sukarami. Bekerjasama dengan Fakultas Pertanian Universitas Andalas. Lokasi Sitiung Sumatra Barat, tahun 1982.

Tan, K. H. 2000. Environmental soil science. Marcel Dekker Inc, New York. NY.

Treseder, K. K. dan K. M. Turner, 2007. Glomalin and ecosystem. Soil Science Society of American Journal, Vol. 71 
(4) : 1257 - 1266, diunduh 27 Desember 2011.

USDA_BIO-RAD BRADFORD PROTEIN ASSAY - USDA Bio-Rad Bradford Total Protein Assay with Sodium Pyrophosphate Modification. Authors (Bradford, 1976; Nichols and Wright, 2004 \& Wright et al., 2006) [Online, unduh 4 September 2012]. Available at www.ars.usda.gov/.../Bradford\%20Tot al\%20Protein\%20Assay.pdf or https://www.pdffiller.com/en/project/1 48138789.htm?f hash=4ec0f2

USDA - GLOMALIN EXTRACTION USDA. Glomalin Extraction with Sodium Pyrophosphate. Authors (Rillig, 2004; Rosier et al., 2007; and Rillig, 2003; Wright et al., 1996; Wright and Jawson, 2001; Wright, Nichols, \& Schmidt, 2006; Wright \& Upadhyaya, 1996; \& Wright \& Upadhyaya, 1998) [Online, unduh 4September 2012]. Available at www.ars.usda.gov/.../ad hoc/54450000 Glomalin/Glomalin\%20Extraction.pdf. or

https://www.researchgate.net/file.Post FileLoader.html?id...

Wright, S. F dan A. Upadhyaya. 1996. Extraction of an abundant an unusual protein from soil and comparison with hyphal protein of arbuscular mycorrhizal fungi. Soil Science, vol. 161 (9) : 575-586, diunduh 4 September 2012.

Wright, S. F. dan A. Upadhyaya. 1998. A survey of soil for aggregate stability and glomalin, a glycoprotein produced by hyphae of arbuscular mycorrhizal fungi. Plant and Soil, Vol. 98 : 97 107, diunduh 27 Desember 2011.

Wright, S. F., K. A. Nichols, L. Jawson, L. McKenna and A. Almendras. 2001. Glomalin-A manageable soil glue. Soil Science Society of America Special publication Book Chapter. 21 Oktober 2001. ARS.USDA.gov. Diunduh 27 Desember 2011. 